\title{
A EDUCAÇÃO ESCOLAR NA CONCEPÇÃO POLÍTICO- PEDAGÓGICA DE PAULO FREIRE
}

\section{SCHOOL EDUCATION IN THE POLITICAL-PEDAGOGICAL DESIGN OF PAULO FREIRE}

\author{
Paulo Roberto da Silva Leal - \\ Universidade Regional do Cariri (URCA) \\ Adriana Maria Simião da Silva - \\ Universidade Regional do Cariri (URCA)
}

\begin{abstract}
RESUMO
O presente trabalho tem como propósito abordar a concepção do filósofo-educador brasileiro Paulo Reglus Neves Freire (Paulo Freire) sobre a educação escolar. Consideramos que o legado freireano possui elevada pertinência por sua originalidade e radicalidade, pois no quadro das teorias educacionais, destaca-se como paradigma ético-político-pedagógico contra hegemônico. Do início ao fim de sua produção educacional, Paulo Freire dedicou-se à crítica do que denominou educação bancária, como também, cunhou e defendeu como alternativa o que chamou de educação libertadora. Estas duas concepções divergentes em finalidades e métodos, expressam no seu entendimento, visões de mundo antagônicas. Uma a serviço da classe dominante e a outra à classe dominada. Sabe-se que o aparelho escolar, no contexto da dominação de classe capitalista é responsável sobretudo pela preservação da ordem social através da reprodução da lógicade opressão sobre as classes oprimidas. Neste sentido é fundamental compreendermos como uma perspectiva da prática educativa escolar, radicalmente contrária a este modo de sociabilidade humana, pode contribuir para a transformação deste sistema, já que universalmente e sistematicamente não pode ser adotada no âmbito escolar pelo seu caráter cultural e politicamente revolucionário. A partir de uma pesquisa bibliográfica, este trabalho tenciona mostrar a existência de uma perspectiva humanista-libertadora de educação escolar presente na literatura educacional de Paulo Freire.
\end{abstract}

PALAVRAS-CHAVE: Capitalismo. Educação. Escola.

\footnotetext{
ABSTRACT

The present work aims to approach the conception of the Brazilian philosopher-educatorPaulo Reglu Neves Freire (Paulo Freire) about school education. We consider that Freire'slegacy is highly relevant for its originality and radicality, because in the context of educational theories, it stands
} 
out as an anti-hegemonic ethical-political-pedagogical paradigm. From the beginning to the end of his educational production, Paulo Freire devoted himself to the critique of what he called banking education, as well as coining and defending as an alternative to what he called liberating education. These two divergent conceptions in purposes and methods express in their understanding antagonistic points of view. One at the service of the ruling class and the other for the ruled class. It is known that the school system, in capitalist class domination context, is the main responsible for the preservation of the social order through the reproduction of the logic of oppression on the oppressed classes. In this sense, it is essential to understandhow a perspective of school educational practice, radically contrary to this mode of human sociability, can contribute to the transformation of this system, since it cannot beuniversally and systematically adopted in the school environment due to its cultural and political revolutionary nature. Based on a bibliographical research, this work intends to show the existence of a humanist-liberating perspective of school education present in Paulo Freire's educational literature.

KEYWORDS: Capitalism. Education. School.

\section{INTRODUÇÃO}

Este trabalho tem como propósito rastrear e expor a concepção políticopedagógica de Paulo Freire sobre a educação escolar. O esforço intelectual para o cumprimento desta tarefa está assentado na convicção de que este educador brasileiro é responsável por produzir uma original e crítica perspectiva sobre a educação formal. Ressalte-se que a sua contribuição enquanto práxis histórica e dialética afirma-se como um paradigma ético-político-pedagógico em defesa dos interesses das classes dominadase superação dos mais variados tipos de opressão, sob o contexto de dominação capitalista.Para Gadotti (2011, p.10): "Depois de Paulo Freire não é mais possível pensar a educaçãocomo um universo preservado, como não foi mais possível pensar a sociedade sem a lutade classes após a dialética de Marx". Isto porque a filosofia e pedagogia de Freire são juntas, expressões de uma clara e consistente opção pela conscientização e libertação dos oprimidos (as), portadores de sua própria emancipação.

Neste sentido, a escola, para Paulo Freire, é um instrumento de fundamental importância para a defesa dos interesses históricos das classes dominadas. Isto significa afirmar a compreensão dialética de Freire sobre as limitações e possibilidades reais do aparelho escolar no interior do modo de sociabilidade capitalista. A defesa de uma escolahumanista e crítica para ele é problemática quando a compreendemos em suas relações de contradição com a 
sociedade mais ampla. A visão de Freire sobre a organização escolarformal merece uma atenção especial. Neste trabalho, tencionamos apreender como ele equaciona a formação crítica no espaço-tempo escolar e como esta pode vincularse ao fortalecimento das lutas sociais contra as formas de dominação e alienação da ordem vigente.

A relevância desta temática também se deve ao fato de que é possível perceber uma dicotomia na apropriação das ideias freireanas. De um lado, Freire é destacado historicamente como o criador de um método revolucionário voltado à educação de jovens e adultos e, do outro, é enaltecido, antes de tudo, por constituir uma densa filosofiada educação. Esta falsa dicotomia é reducionista e impede o entendimento mais sistêmicoe profundo da proposta de Paulo Freire sobre a instituição escolar. Autores de grande envergadura da literatura educacional nacional, como por exemplo, $\operatorname{Libânio}^{1}$ (1994, p. 11) afirma que: "não é próprio da pedagogia libertadora falar em ensino escolar, já que sua marca é a atuação não-formal". É certo dizer que a visão Freireana está restringida à educação de adultos ou à educação popular no geral? A abordagem libertadora tem contribuições ao campo da educação escolar? Some-se a esta questão importante, as distorções de natureza idealista e reformista que minimizam a dimensão político- revolucionária de seu pensamento educacional.

Este trabalho, de cunho teórico, foi realizado mediante pesquisa bibliográfica. Quesegundo Severino pesquisa bibliográfica:

[...] é aquela que se realiza a partir do registro disponível, decorrente de pesquisas anteriores, em documentos impressos, como livros, artigos, teses, etc. Utiliza-se de dados ou de categorias teóricas já trabalhados por outros pesquisados e devidamente registrados. Os textos tornam-se fontes dos temas aserem pesquisados. O pesquisador trabalha a partir das contribuições dos autores dos estudos analíticos constantes dos textos. (FREIRE, 2007, p. 122),

A pesquisa aconteceu, fundamentalmente a partir da análise dos próprios textos de Paulo Freire. Contamos, ainda com as contribuições de outros autores clássicos como: Teixeira (1967), Althusser (1985) e Marx; Engels (2005). Acreditamos que este trabalhopossui pertinência acadêmica por analisar também as críticas de Paulo Freire à educaçãobancária, enquanto concepção educativa

${ }^{1} \mathrm{O}$ texto do educador José Carlos Libânio chama-se: Tendências Pedagógicas na Prática Escolar e podeser encontrado no livro: Filosofia da Educação do professor Cipriano Carlos Luckesi 
escolar a serviço dos interesses das classes dominantes e por conter também, ainda que de maneira introdutória, uma apresentação de sua proposta educativa no âmbito formal, expressão dos interesses das classes oprimidas na sociedade capitalista. Ou seja, um paradigma ético-político-pedagógico de caráter humanista-revolucionário.

\section{A CRÍTICA FREIREANA À EDUCAÇÃO ESCOLAR BANCÁRIA}

A História da educação brasileira registra a exclusão da maioria do conjunto do povo dos processos educativos escolares; demonstrando a utilização desta como instrumento reforçador, reprodutor e legitimador de sua força político-econômica sobreas classes dominadas e exploradas. Devemos recordar a dualidade contraditória desde processo histórico: de um lado, elites conservadoras e reacionárias, lutando para a preservação do status quo, e do outro, as camadas populares lutando por seus direitos, ou seja, ansiando por libertação. Paulo Freire, já na segunda metade do século XX, aparece como crítico da realidade brasileira. A perspectiva libertadora da educaçãoescolar ganhou maturidade teórica no pensamento freireano, também no processo de crítica ao que ele denominou de educação bancária.

Historicamente, desde Educação e Atualidade Brasileira (1959) à Pedagogia da Autonomia (1996) são explicitadas as razões pelas quais freire critica o modelo bancário em benefício do que chamou: libertador. Isto nos leva a convicção de que para compreendermos a abordagem libertadora da educação escolar defendida por ele, precisamos analisar suas críticas à educação bancária. Paulo Freire é um educador quedeseja corroborar em pensar um projeto de nação para o Brasil. Suas críticas ao modelo educacional escolar não podem ser entendidas em si mesmas, porque estão articuladas as críticas que ele fazia à conjuntura econômica, política e cultural das décadas de 1950,1960 e 1970.

$\mathrm{Na}$ primeira obra de Freire, estão claros os objetivos educacionais escolares brasileiros, a saber: desenvolvimento econômico e a mentalidade democrática. Para ele,o contexto histórico-cultural brasileiro dava claros sinais de que a educação havia se tornado uma problemática nacional candente. Vejamos, por exemplo, a seguinte passagem de Educação e Atualidade Brasileira (1959): 
grande, é desses que precisam ser vistos organicamente. Precisam ser vistos do ponto de vista de nossa atualidade. No jogo de suas forças, algumas ou muitas dentre elas, em antinomia uma com as outras. Todo planejamento educacional para qualquer sociedade, tem que responder às marcas e aos valores dessa sociedade. Só assim é que pode funcionar o processo educativo, ora como força estabilizadora, ora como fator de mudança. Às vezes preservando determinadas formas de cultura. Outras, interferindo no processo histórico, instrumentalmente. De qualquer modo, para ser autêntico, é necessário ao processo educativo que se ponha em relação de organicidade com a contextura da sociedade a que se aplica. (FREIRE, 2003, p. 10).

Paulo Freire compreendia que esta relação de inorganicidade da educação em posição à nova fase do país prejudicava de forma acentuada os objetivos citados acima, o que implicaria uma "[...] revisão urgente e total de nossa educação, quase toda ela decorativa e seletivamente antidemocrática." (FREIRE, 2003, p. 43). Isto demandava a democratização da escola as grandes massas urbanas analfabetas, articulada a formaçãode novas disposições mentais próprias do novo clima cultural.

$\mathrm{Na}$ esteira escolanovista, ele acusava o modelo pedagógico de ser desvinculado da vida do educando e da sua realidade local, regional e nacional. Acusava, ainda denão incentivar o diálogo, a participação, a criticidade, mas ao contrário, de reforçar a inexperiência democrática, ao ser excludente, autoritária, assistencializadora e verbalista.

Em vários momentos da obra Educação e Atualidade Brasileira (1959), Freire citae concorda com o também educador brasileiro Anísio Teixeira, para quem a educação deveria estar integrada ao contexto concreto do educando e ser integradorae propedêutica. Ou seja, tratava-se de preparar as novas gerações às demandas postas pelo novo cenário econômico, político e cultural.

Em Educação como Prática da Liberdade (2013), são retomados de maneira aperfeiçoada os temas abordados na obra anterior com o acréscimo da sistematização de uma metodologia capaz de realizar na alfabetização de adultos os objetivos filosóficos, políticos e pedagógicos. A sistematização teórico-prática desta experiência lhe rendeu reconhecimento nacional. Para Freire, a educação escolar reforçava a alienação política e cultural do homem brasileiro. Os procedimentos didático-pedagógicos inflexíveis, mecânicos, passivos, descontextualizados e acríticos eram expressões concretas do cenário conservador, reacionário e autoritário mais amplo. Segundo Freire: 
nosso estudante o gosto da pesquisa, da constatação, da revisão dos achados - o que implicaria o desenvolvimento da consciência transitivo-crítica. Pelo contrário, a sua perigosa superposição à realidade, intensifica no nosso estudante a sua consciência ingênua. A própria posição da nossa escola de modo geral acalenta ela mesma pela sonoridade da palavra, pela memorização dos trechos, pela desvinculação da realidade, pela tendência a reduzir os meios de aprendizagem às formas meramente nocionais já é uma posição caracteristicamente ingênua. (FREIRE, 2003, p. 125).

As práticas educativas negavam a "vocação ontológica do homem", ou seja, a deser sujeito em sua realidade concreta. Os componentes do processo educativo escolar (professor, sala de aula, conteúdo e aluno) carregavam uma tradição mais autoritária e alienadora que dialógica e emancipadora. As práticas educativas de alfabetização de adultos pelo Brasil através do que foi chamado "Método Paulo Freire2" comprovavam que estes elementos e relações precisavam se reestruturar em novos termos e dinâmica.

\footnotetext{
2 Paulo Freire com a colaboração de um grupo de estudantes, em princípios de 1963, na cidade de Angicos (RN), pôs em prática o seu famoso método de alfabetização de adultos. Fazendo com que os participantesaprendessem a ler e escrever e, ainda por cima, viessem a se politizar em 40 horas.
}

Para Freire, esta educação escolar de ideias inertes, "[...] desvinculada da vida, centrada na palavra." (FREIRE, 2003, p. 124), não poderia levar o educando a análise da realidade, à discussão de seus problemas e a intervir criticamente nesta mesma realidade. Freire estava convicto de que a formação do povo brasileiro crítico edemocrático demandava uma nova escola que fosse crítica e democrática em suas práticas pedagógicas.

Críticas também fortemente baseadas nas análises de Anísio Teixeira, para quema reconstrução educacional tornava-se uma exigência de concretização sob pena de permanecer um país atrasado em relação as novas condições econômicas, políticas e democráticas. Tanto para Anísio Teixeira como para Paulo Freire, a reforma educacional impactaria diretamente na formação do povo e no desenvolvimento brasileiro em todos os sentidos.

Uma perspectiva otimista que colocava sob a escola o posto de reivindicação nacional por excelência e instituição mais cara à realização dos anseios do país. O discurso de Anísio Teixeira na obra, Educação Não é Privilégio é ilustrativo, onde nosapresenta que, 
Nesse processo de reconstrução, nenhum problema é mais essencial do que o da escola, pois por ela é que se efetivará o novo senso de consciência nacional e se afirmará a possibilidade de se fazer permanente e progressiva a grande mobilização do esforço brasileiro. (TEIXEIRA, 1967, p. 83).

A educação escolar do país caminhava em sentido contrário a estas exigências políticas e culturais. Em Educação como Prática da Liberdade, Freire é categórico:

Como aprender a discutir e a debater com uma educação que impõe? Ditamos ideias. Não trocamos ideias. Discursamos aulas. Não debatemos ou discutimos temas. Trabalhamos sobre o educando. Não trabalhamos com ele. Impomos-lhe uma ordem a que ele não adere, mas se acomoda. Não lhe propiciamos meios para pensar autêntico, porque, recebendo as fórmulas que lhe damos, simplesmente as guarda. Não as incorpora porque a incorporação é o resultado de busca de algo que exige, de quem o tenta, esforço de recriação e de quem procura. Exige reinvenção. (FREIRE, 2003, p. 127).

As obras: Educação e Atualidade Brasileira (1959) e Educação Como Prática da Liberdade (1965) demonstram a insatisfação de Paulo Freire com o modelo educacionalem suas relações com a conjuntura econômica, política e cultural brasileira. Todas as expressões e termos de crítica à educação nestas obras formaram os elementos iniciaisde uma sistematização consistente, clara e radical do que passou a ser denominada a partir de Pedagogia do Oprimido (1968) de educação bancária. Nas obras anteriores, acrítica escolar do Brasil tem a sua solução em uma proposta reformadora e conciliadorade classes.

Em Pedagogia do Oprimido (1968), tendo sido influenciado de forma significativa pelo marxismo, Freire conclui que os objetivos políticos-ideológicos da classe dominante não são e nem podem ser os mesmos da classe dominada, portanto, visões radicalmente antagônicas de mundo só podem construir projetos educativos também inconciliáveis. É por isso que a educação bancária não corresponde às necessidades ou interesses da classe trabalhadora. O que está no centro da questão é mais do que um conflito de tendências pedagógicas; é o conflito fundamental da sociedade, ou seja, a luta de classes.

A concepção bancária da educação está assentada em pressupostos antropológicos, filosóficos, psicológicos, sociológicos, e políticos que compreendem oser humano em seu processo de educação, como ser de e sujeito à passividade, acomodação, alienação, desumanização, etc. Ela expressa em 
objetivos e formas o projeto político-educativo das classes dominantes às classes dominadas. Em qualquer nível educacional, através de variadas tendências pedagógicas, históricas e culturalmente construídas, é reforçada a ordem capitalista vigente. Em Ação Cultural para a Liberdade e outros escritos, Paulo Freire constata:

\begin{abstract}
Neste, a escola não importa qual seja o seu nível, vem desempenhando um papel dos mais importantes, como eficiente instrumento de controle social. Não são raros os educadores para quem "educar é adaptar o educando a seu meio" e a escola, em regra não vem fazendo outra senão isto. (FREIRE, 2011, p. 164).
\end{abstract}

Freire também dialoga com o pensamento marxista de Louis Althusser ao reconhecer que a escola é um aparelho ideológico do estado. A educação bancária reproduz uma perspectiva conservadora da sociedade. Vejamos o que Althusser em sua obra, Aparelhos Ideológicos do Estado, fala sobre a escola enquanto mecanismo de reprodução das formas de produção e relações capitalistas:

[...] ao mesmo tempo, e junto com essas técnicas e conhecimentos, aprendem-se nas escolas as "regras" do bom comportamento, isto é, as conveniências que devem ser observadas por todo agente da divisão do trabalho conforme o posto que ele esteja "destinado" a ocupar; as regras de respeito à divisão social-técnica do trabalho e, em definitivo, regras da ordem estabelecida pela dominação classe. (ALTHUSSER, 1989, p. 58).

Em Política e Educação, Freire (2014, p. 62) explica que "não há como negarque esta é a tarefa que as classes dominantes de qualquer sociedade burguesa esperamde suas escolas e de seus professores". Fica claro dessa forma que a educação tem umanatureza política. Isto, diga-se de passagem, independe da vontade docente. Asconcepções e práticas no interior das escolas possuem intenções políticas. Para PauloFreire, a educação que deseje ser ou ter uma qualidade libertadora não pode utilizar-se das concepções e práticas de dominação da educação bancária, pois são radicalmenteantagônicas, como ressalva: 'Daí que a educação bancária, que a eles serve, jamaispossa orientarse no sentido da conscientização dos educandos”. (FREIRE, 2011, p. 85).

Uma das expressões práticas da educação bancária no cumprimento de sua função de mantenedora das relações de opressão está na contradição construída e alimentada entre educador versus educando. No modelo educativo em questão, Paulo Freire, detalha na obra Pedagogia do Oprimido como acontece 
esta relação de antinomia:

Na concepção "bancária" que estamos criticando, para a qual a educação é o ato de depositar, de transferir, de transmitir valores e conhecimentos, não se verifica nem pode verificar-se esta superação. Pelo contrário, refletindo a sociedade opressora, sendo dimensão da "cultura do silêncio", a "educação bancária" mantém e estimula a contradição. Daí, então, que nela: (FREIRE, 2011, p. 82-83).

a) O educador é o que educa; os educandos, os que sãoeducados;

b) O educador é o que sabe; os educandos, os quenão sabem;

c) O educador é o que pensa; os educandos,os pensados;

d) O educador é o que diz a palavra; os educandos, os que a escutamdocilmente;

e) O educador é o que disciplina; os educandos, osdisciplinados;

f) O educador é o que opta e prescreve sua opção; os educandos, osque seguem a prescrição;

g) O educador é o que atua; os educandos, os que têm a ilusão de queatuam, na atuação do educador;

h) O educador escolhe o conteúdo programático; os educandos, jamaisouvidos nesta escolha, se acomodam a ele;

i) O educador identifica a autoridade do saber com sua autoridade funcional, que opõe antagonicamente à liberdade dos educandos; estesdevem adaptar-se às determinações daquele;

j) O educador, finalmente, é o sujeito do processo; os educandos, meros objetos.

O educando, considerado "tábula rasa" e/ou recurso humano em potencial, tem oseu desenvolvimento profundamente prejudicado, ou melhor, o seu desenvolvimento integral é impossível sob tal modelo vigente. Os esquemas verticalizados, burocráticos, classificatórios, impessoais, são de sobremaneira responsáveis por criarem processos de alienação política e cultural, como fortalecem perspectivas fatalistas da história e naturalizam relações baseadas na opressão. Na condição de ser imerso frente à realidade,preso à situações-limite, o educando não desvela o mundo muito menos intervém nele de maneira crítica. 
A lógica intelectualista, produtivista, geradora e reforçadora de competição desta concepção pedagógica, impede a compreensão da historicidade e problematicidadedo saber e tem como finalidade através de procedimentos passivos e/ou ativos à adaptaçãodo educando ao mundo capitalista. Em sua obra Por uma Pedagogia da Pergunta, Paulo Freire esclarece que,

\begin{abstract}
Embrutecer a força de trabalho submetida a procedimentos rotineiros faz parte da natureza do modo de produção capitalista. O que se dá na produção do conhecimento na escola é, em grande parte, mesmo que possamos fazer o contrário, a reprodução desse mecanismo. $\mathrm{Na}$ verdade, quanto mais se "embrutece" a capacidade inventiva e criadora do educando, tanto mais ele é apenas disciplinado para receber "respostas" a perguntas que não foram feitas, como salientamos antes. Quanto mais se adapta o educando a talprocedimento, tanto mais ironicamente se pensa que essa é uma educação produtiva. No fundo, essa é uma educação que reproduz o autoritarismo do modo de produção capitalista. (FREIRE, 2011, p. 78).
\end{abstract}

É importante ressaltar que a existência da pedagogia ou educação bancária para Freire, após a produção de Pedagogia do Oprimido (1968), deve-se a existência de uma sociedade dividida em classes. Portanto, a pedagogia dominante será necessariamente a pedagogia da classe dominante. Tendo superado uma perspectiva liberal-democrática dos primeiros escritos, a crítica à educação fortemente marcada por conteúdos e formasalienadoras e dominadoras, dá vida ao seu contraditório, ou seja, a educação libertadora,como proposta contra hegemônica das classes dominadas.

Neste sentido, a educação bancária, como educação da classe dominante àdominada, revestida sob diversas pedagogias e metodologias, é capaz de não só colaborar para a reprodução das desigualdades sociais e culturais, como também gerar nos sujeitos envolvidos no processo educativo escolar a "falsa consciência", ou melhor, as representações alienantes nos próprios discursos e comportamentos dos oprimidos, tornando-os seres com uma "consciência hospedeira da opressão". O que os faz tomarem parte em sua condição de submissos e desumanizados, pois estes internalizam passivamente/ativamente e assim legitimam as visões hegemônicas de mundo. 


\section{A PRÁXIS EDUCATIVA ESCOLAR LIBERTADORA DE PAULO FREIRE}

Enquanto perspectiva crítica à educação bancária, a libertadora, dandose no ambiente escolar, possui limites frente às múltiplas determinações, mas também possibilidades quando entendida em suas relações dialéticas com a prática social mais ampla da sociedade capitalista. Neste sentido, Paulo Freire propõe uma abordagem da educação formal de natureza política e efetivada através da ação consciente e comprometida de educadores (as) identificados com a superação da ordem social capitalista.

A Pedagogia Libertadora, assim nomeada por Paulo Freire, apenas poderá ser bem compreendida se relacionada dialeticamente aos seus condicionantes econômicos,políticos, culturais. Esta abordagem, de natureza crítica, afirma-se como proposta superadora das perspectivas otimistas-ingênuas e pessimistas quanto às relações entre educação escolar e sociedade, diga-se, capitalista.

Para Freire, a educação escolar, se analisada criticamente, não pode ser elevada àcondição de redentora da sociedade; muito menos, como puro reflexo desta. Em Ação Cultural para a Liberdade e outros escritos, Freire equaciona esta relação da seguinte forma:

Se me ponho numa posição idealista, dicotomizando consciência e realidade, submeto esta àquela, como se a realidade fosse constituída pela consciência. Assim, a transformação da realidade se dá pela transformação da consciência. Se me ponho numa posição mecanicista, dicotomizando igualmente consciência e realidade, tomoa consciência como um espelho que apenas reflete a realidade. Em ambos os casos, nego a conscientização que só existe quando não apenas reconheço, mas experimento a dialeticidade entre objetividade e subjetividade, realidade e consciência, prática e teoria. (FREIRE, 2011, p. 237).

Esta compreensão indica o ser humano, como ser condicionado, mas não determinado. O que aliás dialoga com o pensamento marxiano, quando na terceira tese sobre Feuerbach, lê-se, '[...] a doutrina materialista da transformação das circunstâncias e da educação esquece que as circunstâncias têm de ser transformadas pelos homens [...]" (MARX; ENGELS, 2005, p. 122).

Apenas ele é capaz de conhecer a realidade, saber-se condicionado e reagir aos fatores que o dominam. A realidade objetiva produzida pelo capitalismo, alienante e desumana, é resultado da própria ação humana dividida 
entre grupos ou classes com interesses conflitantes, o que Freire chama de opressores e oprimidos. Sua posição em defesa da desnaturalização e superação desde antagonismo sugere a transformação da realidade social pela ação consciente dos oprimidos (as).

A Pedagogia libertadora defende neste sentido um possível e necessário papelhistórico-transformador dos homens e mulheres oprimidos (as), que nos processos deluta contra o seu antagônico constroem objetivos e formas opostas aos daquele. ParaFreire esta pedagogia crítica não pode ser forjada pelos opressores, pois seuspressupostos filosóficos e políticos almejam fazer “[...] da opressão e de suas causasobjeto da reflexão dos oprimidos, de que resultará o seu engajamento necessário na lutapor sua libertação.” (FREIRE, 2011, p. 43).

Para Paulo Freire é imprescindívelreconhecer que a educação escolar, enquanto processo intencional e sistemático, éprofundamente marcada pela reprodução da ideologia dominante, ou seja, da visão demundo burguesa. Isto acontece, mediante uma prática educativa bancária, que implicauma formação humana passiva e/ou ativa, mas sempre acomodada ao mundo capitalista.Este reconhecimento de que a educação formal é aparelho de reprodução ideológica dominante é apenas uma dimensão do papel dialético desta instituição. DizFreire (2011, p. 36): “[...] as relações entre educação enquanto subsistema e o sistema maior são relações dinâmicas, contraditórias e não mecânicas."

Isto significa que aescola não é absolutamente autônoma, mas também não é absolutamente dependentedos condicionamentos econômicos e políticos do capitalismo. Segundo Freire (1996, p.99) “[...] é um erro decretá-la como apenas reprodutora da ideologia dominante como erro é torná-la como força da desocultação da realidade [...]”. Portanto, não é neutra e muito menos à alavanca das transformações sociais. Para Freire, a luta no campo escolar, em tudo o que lhe é específico, pode e deve se dar dentro e contra a ordem vigente. Esta luta, articulada organicamente as lutas sociais mais amplas, pode contribuir de forma significativa para uma perspectiva educativa de natureza crítica.

Recusando leituras funcionalistas e economicistas sobre o papel da educação escolar em suas relações com a sociedade capitalista, Freire aponta os "trabalhos educativos", construídos pelas classes dominadas e em função de seus interesses, como possibilidades reais de concretização em um contexto de dominação de classe. Procuraafastar-se também de concepções idealistas, que 
propõem mudanças substanciais no mundo, a partir de projetos educativos que almejam a transformação da consciência e/ou a conciliação de antagônicos.

A pedagogia libertadora de Paulo Freire afirma-se como paradigma éticopolítico-pedagógico de classe. Da classe dominada contra a classe dominante para a superação da opressão de todo tipo e permanente humanização de todos os homens e mulheres. Em Ação Cultural para a Liberdade e outros escritos, Paulo Freire explica ainda que:

\begin{abstract}
A educação libertadora não pode ser a que busca libertar os educandos de quadros-negros para oferecer-lhes projetores. Pelo contrário, é a que se propõe, como prática social, a contribuir para a libertação das classes dominadas. Por isso mesmo, é uma educação política, tão política quanto a que, servindo às classes dominantes, se proclama, contudo, neutra. Daí que uma tal educação não possa ser posta em prática, em termos sistemáticos, antes da transformação revolucionária da sociedade. (FREIRE, 2011, p. 177).
\end{abstract}

No que diz respeito à escola pública, escola em que estão os trabalhadores (as) e seus filhos (as), é possível compreender a partir desta perspectiva como estão equacionados os limites e possibilidades desta escola no interior da luta de classes e como pode agir o educador (a) identificado com a visão de mundo freireana. A questãobasilar desta pedagogia de natureza crítica é saber que a educação não é a alavanca dastransformações sociais e que ao mesmo tempo pode ser imputado a ela contribuições importantes. Assim, expressa Freire:

Precisamente porque a educação não é a alavanca para a transformação da sociedade, corremos o perigo do desespero e do ceticismo, se limitarmos nossa luta à sala de aula. $\mathrm{O}$ que devemos fazer, creio eu desde o início da nossa experiência como professores, é estar criticamente consciente dos limites da educação. Isto é, saber que a educação não é a alavanca, não esperar que ela vá realizar a grande transformação social. Devemos saber que é possível conseguir algumas coisas importantes no espaço institucional de uma escola, oufaculdade, para ajudar a transformação da sociedade. Se compreendermos como a educação formal se relaciona com a sociedade global, sem ser, apenas, a reprodutora da ideologia dominante, e sem ser, também a principal alavanca da transformação;se compreendermos desse modo nossa prática educacional, evitaremos, então, um certo otimismo ingênuo que pode levar-nos no futuro, a um terrível pessimismo. Ao evitar o otimismo ingênuo no início, estaremos evitando cair no desespero e no ceticismo. (1986. p. 157).

A prática pedagógica do (a) educador (a) para Paulo Freire precisa estar profundamente consciente da relação de autonomia relativa da escola em face da sociedade capitalista. Não espera ingenuamente, por exemplo, que as classes burguesaspromovam todas as condições materiais e imateriais necessárias para 
efetivação de umapedagogia crítica. Para ele, toda concepção educativa que não parta da análise dos condicionamentos econômicos, políticos e ideológicos, corre o risco de responsabilizar à educação escolar um papel que ela não pode desempenhar sozinha.

Por isso, ele defende que na prática do (a) educador (a) não estejam dicotomizados clareza política e competência pedagógica para que as lutas do campo educativo escolarse articulem aos conflitos sociais mais amplos. Em Medo e Ousadia: O Cotidiano do Professor, Freire explica como precisa ser compreendido o trabalho pedagógico escolar em conexão ao necessário engajamento político:

Devemos evitar que nos interpretem corno se estivéssemos pensando que deveríamos primeiro educar as pessoas para seremlivres, para depois podermos transformar a realidade. Não. Devemos o quanto possível, fazer as duas coisas simultaneamente. Por isso, devemos estar engajados na ação política contra o racismo, contra o sexismo, contra o capitalismo, e contra as estruturas desumanas de produção. (FREIRE,1986, p. 199).

$\mathrm{O}$ educador (a) que vai constituindo-se cotidianamente freireano (a) precisa compreender as complexas relações entre a escola e a sociedade capitalista. A adequadaanálise desta relação o (a) faz entender os limites da ação educativa escolar dentro de um contexto de dominação de classe e as possibilidades reais que tem ou pode construirpara viabilizar o processo educativo-crítico que pretende. Se não pode cair em idealismos, também não pode sucumbir ao economicismo, já que estas leituras da sociedade burguesa apenas fortalecem a opressão em que se encontram a classedominada. Para Freire, "[...] enquanto a transformação radical não se dá, há espaços aserem ocupados.” (FREIRE, 2008, p. 74).

Paulo Freire defende que a escola pública precisa ser defendida enquanto espaço-tempo de luta contra a ideologia dominante, ou seja, contra discursos e práticasopressoras. A organização escolar formal tem um papel fundamental no processo de formação da consciência crítica das classes dominadas. Essa tomada de consciência é fundamental a uma intervenção transformadora da realidade.

Ele advoga uma práxis político-pedagógica que, ao invés de acomodar indivíduos à estrutura social opressora,problematiza, desvela, denuncia e anuncia uma nova realidade a ser criada por homense mulheres oprimidos (as) da sociedade de classes. Segundo sua visão, este modelo pedagógico não pode ser exercido por educadores (as) a serviço do sistema atual. Em Política e Educação, 
ele observa que:

Se a reprodução da ideologia dominante implica, fundamentalmente, a ocultação de verdades, a distorção da razão de ser de fatos que, explicados, revelados ou desvelados, trabalhariam contra os interesses dominantes, a tarefa das educadoras e dos educadores progressistas é desocultar verdades, jamais mentir. A desocultação não é de fato tarefa para os educadores a serviço do sistema. Evidentemente, numa sociedade de classes como a nossa, é muito mais difícil trabalhar em favor da desocultação, que é um nadar contra a correnteza, do que trabalhar ocultando, que é um nadar a favor da correnteza. É difícil, mas possível. (FREIRE, 2014, p. 115-116).

O que não é possível é a neutralidade política da prática educativa escolar. Consciente ou inconscientemente educa-se sempre a favor e/ou contra alguém. Sendo assim, necessita-se de um (a) educador (a) de novo tipo. Nem ingênuo nem astuto. O educador (a) ingênuo transfere à educação que promove um poder quase absoluto, por isso, tende ao psicologismo, romantismo, democratismo, politicismo e pessimismo.

O educador (a) astuto, por outro lado, está ciente das contradições em que se acha a educação escolar, porém, opta pelo silêncio, omissão, ajusta-se e evitando o conflito político-pedagógico, reforça os interesses da classe dominante. A politicidade dapedagogia freireana demanda um educador (a) que busca estabelecer uma relação de coerência entre seus objetivos políticos-pedagógicos liberadores e suas formas metodológicas de atuação. O que faz desta perspectiva um paradigma ético para à ação educativa-crítica. Aqui, a coerência é uma qualidade que não pode estar ausente da prática educativa libertadora.

Neste sentido, para atingir as finalidades proclamadas, o educador (a) necessariamente recorrerá a formas de ação radicalmente divergentes dos métodos pedagógicos efetivados em práticas educativas que objetivam a alienação e não a criticidade. Para Freire, a coerência político-pedagógica do (a) educador (a) é a expressão concreta da autenticidade de uma posição política libertadora. "É que sabemmuito bem que não é o discurso o que ajuíza a prática, mas a prática que ajuíza o discurso.” (FREIRE, 2011, p. 37).

Esta ênfase ao caráter político da educação não está desarticulada da função social da instituição escolar, ou seja, a socialização dos conteúdos. Na pedagogia freireana o ato de ensinar-aprender é um processo de conhecimento e de politização. Se na prática educativa bancária o aprender é o ato de burocratização da mente e de adaptação do educando à realidade dada e 
alienante, a prática educativa libertadora consiste em associar dialeticamente a leitura do mundo com a leitura da palavra.

Como já destacado, para Freire, a clareza política está sempre condicionada à competência pedagógica, como esta àquela e ambas estão a serviço de um processo educativo escolar em que a democratização do saber é compreendida de maneira crítica.Em Política e Educação, ele explica como esta relação está equacionada:

\begin{abstract}
Há outra tarefa a ser cumprida na escola apesar do poder dominante e por causa dele - a de desopacizar a realidade enevoada pela ideologia dominante. Obviamente, esta é a tarefa dos professores e das professoras progressistas que estão certos de que têm o dever de ensinar competentemente os conteúdos, mas também estão certos de que, ao fazê-lo, se obrigam a desvelar o mundo da opressão. Nem conteúdo só, nem desvelamento só, como se fosse possível separá-los, mas o desvelamento do mundo opressor através do ensino dos conteúdos. O cumprimento dessa tarefa progressista implica ainda a luta incansável pela escola pública, de um lado, e de outro, o esforço para ocupar o seu espaço no sentido de fazê-la melhor. Esta é uma luta que exige claridade política e competência científica. (FREIRE, 2014, p. 62).
\end{abstract}

Nesse sentido, conhecer pressupõem uma atitude crítica de ambos os sujeitos envolvidos no processo pedagógico, mediatizados pelo objeto cognoscível. Para Freire,esta situação gnosiológica é marcada não pela transferência de um saber acabado e neutro pelo professor ao aluno, como na educação bancária, mas através da relação dialógica que, problematizando o conhecimento, promove a superação da curiosidade ingênua pela curiosidade epistemológica, da consciência ingênua pela consciência crítica, do conhecimento preponderantemente sensível por um conhecimento, que, partindo do sensível, alcance a razão da realidade.

Na filosofia educacional de Paulo Freire destaca-se essencialmente como proposta humanista de educação escolar. A práxis educativa libertadora pressupõe um conjunto de saberes, princípios e condutas organicamente articulados à opção política ea competência pedagógico-científica do educador (a) de perspectiva crítica. Em suas palavras:

[...) quando vivemos a autenticidade exigida pela prática de ensinaraprender participamos de uma experiência total, diretiva, política, ideológica, gnosiológica, pedagógica, estética e ética, em que a boniteza deve achar-se de mãos dadas com a decência e com seriedade.(FREIRE, 1996, p.24).

Entendida a educação como processo de formação humana em seu 
sentido maisamplo e não como treinamento, a prática do (a) educador (a) de perspectiva libertadoraexpressa em seu modo de ser e relacionar-se qualidades indispensáveis ao fazerdocente-crítico. Estas qualidades se forjam na própria relação com a prática refletida e contribuem por legitimar os propósitos defendidos pelo próprio educador (a). Neste sentido a práxis do (a) educador (a) crítico é permeada de eticidade. Segundo Freire, à docência: "[...] é profundamente formadora, por isso, ética. Se não se pode esperar de seus agentes que sejam santos ou anjos, pode-se e deve-se exigir seriedade e retidão." (FREIRE, 1996, p. 65). Ou seja, sem o que Paulo Freire chama de "corporeificação daspalavras pelo exemplo", sem uma prática "testemunhal" de uma visão de mundo libertadora, não há consistência e autenticidade na opção políticopedagógica o que torna a práxis educativa escolar freireana uma multidimensionalidade em busca de integração entre a lucidez política, a competência didático-pedagógica e o compromissoético.

\section{CONSIDERAÇÕES FINAIS}

Com este trabalho, pudemos evidenciar a defesa indispensável e intransigente quePaulo Freire faz da organização escolar formal. Trata-se de uma característica que perpassa a obra freireana, ou seja, desde sua obra Educação e Atualidade Brasileira (1959) até Pedagogia da Autonomia (1996). Sua crítica radical-dialética à escola não sugere, de maneira alguma, sua negação. Muito pelo contrário, seu olhar em torno destainstituição de educação formal sempre esteve condicionado a um otimismo político- pedagógico substantivamente crítico. Em um primeiro momento de sua obra, com traçoreformista, conciliador e liberal.

A partir de Pedagogia do Oprimido (1968), com forteteor radical. Esta inflexão teórica é compreensível e natural, principalmente se acompanhamos a historicidade e dialeticidade de sua práxis enquanto um educador- educando que, pensando a prática, reelaborou e amadureceu sua teoria, a fim de melhor apreender e intervir na realidade objetiva. A partir da exposição e análise deste artigo, fica claro que o legado freireano é um paradigma ético-político-pedagógico contra- hegemônico.

Para Paulo Freire, o sistema educacional escolar também expressa a contradição fundamental da sociedade, ou seja, o antagonismo das classes sociais. 
As classes/grupos dominantes destinam às classes dominadas um processo educativo alienador na busca de uma aceitação passiva e/ou ativa destas ao modo de sociabilidade capitalista. Por isso, o combate a educação bancária tem por base uma opção política que rejeita a perspectiva neoliberal de que não existe mais alternativa ao sistema atual.

Os processos didático-pedagógicos que constituem a educação bancária compreendem o ser humano em suas relações com os conhecimentos socializados no ambiente escolar, de maneira passiva, a-histórica, acabada, autoritária, acrítica, epretensamente neutra. Portanto, essa educação não pode interessar a classe trabalhadorae aos seus (as) filhos (as).

A fim de não cairmos em idealismos e muito menos em uma visão de cunho fatalista-pessimista, há de partir desta constatação freireana: o aparelho escolar está voltado à manutenção consentida da sociedade de classes. Isto significa formar as novasgerações segundo os interesses e necessidades da ordem vigente. Isto, contudo, não significa desconsiderar, o papel da organização escolar formal para a luta da classe trabalhadora contra o capital. Considerando que esta luta pode e deve ser potencializadapela dimensão cultural, a organização escolar formal é indispensável à elevação intelectual e política das classes subalternas.

Este paradigma educativo busca estabelecer a articulação necessária entre a socialização crítica do conhecimento escolar com o propósito de construir e/ou fortalecer a emancipação política. Como horizonte mais amplo de construção, a pedagogia crítico-radical libertadora está voltada para à superação revolucionária do capitalismo, na direção de uma sociedade radicalmente democrática, econômica, política e culturalmente, ou seja, socialista. Isto só é possível pela ação consciente e organizada por parte dos portadores da transformação e humanização do mundo: os oprimidos (as).

A obra freireana é profundamente original e atual. Ela é provocadora e convocadora à militância em torno da defesa de uma educação escolar que, articulada a um projeto de sociedade divergente da capitalista, educa para a emancipação, também por dentro e contra este modelo de produção e de alienação. 


\section{REFERÊNCIAS}

ALTHUSSER, Louis. Aparelhos Ideológicos de Estado: nota sobre os aparelhos ideológicos de Estado [tradução de Walter José Evangelista e Maria Laura Viveiros deCastro: introdução crítica de José Augusto Guilhon Albuquerque]. $12^{\circ}$ ed. Rio de Janeiro:Edições Grall, 1985.

FREIRE, Paulo. Medo e Ousadia: O cotidiano do professor. Rio de Janeiro: Paz e Terra, 1986.

Pedagogia da Autonomia: saberes necessários à prática educativa. $40^{\circ}$ ed.São Paulo: Paz e Terra, 1996.

Política e Educação. [Organização Ana Maria de Araújo Freire]. $1^{\circ}$ ed. SãoPaulo: Paz e Terra, 2014.

Educação como Prática da Liberdade. $15^{\circ}$ ed. Rio de Janeiro: Paz e Terra,2013.

Ação Cultural para a Liberdade e outros escritos. $14^{\circ}$ ed. Rio de Janeiro:Paz e Terra, 2011.

Educação e Mudança. $2^{\circ}$ ed. São Paulo: Paz e Terra, 2011.

FAUNDEZ, Antônio. Por uma pedagogia da pergunta. $7^{\circ} \mathrm{ed}$. São Paulo:Paz e Terra, 2011.

Pedagogia do Oprimido. $50^{\circ}$ ed. Rio de Janeiro: Paz e Terra, 2011.

Educação e Atualidade Brasileira. $3^{\circ}$ ed. São Paulo: Cortez, Instituto PauloFreire, 2003.

GAdOTTI, Moacir; FREIRE, Paulo; GUIMARÃES, Sérgio. Pedagogia: diálogo econflito. $8^{\circ}$ ed. São Paulo: Cortez, 2008.

LUCHESI, Cipriano Carlos. Filosofia da Educação. São Paulo: Cortez, 1994.

MARX, Karl; ENGELS, Friedrich. A ideologia alemã: teses sobre Feuerbach. $8^{\circ}$ ed.São Paulo: Centauro, 2005.

SEVERINO, Antônio Joaquim. Metodologia do trabalho científico. $23^{\circ}$ ed. São Paulo:Cortez, 2007.

TEIXEIRA, Anísio. Educação não é privilégio. $2^{0}$ ed. São Paulo: Editora Nacional,1967. 


\section{Sobre os autores:}

Paulo Roberto da Silva Leal: Graduado em Pedagogia pela Universidade Regional do Cariri (Urca). Localizada na cidade do Crato, Ceará.Especialista em Psicologia Aplicada à Educação pela Universidade Regional do Cariri (Urca). Estudante do curso de Gestão Escolar pela Universidade Regional do Cariri (Urca). Participante do Grupo de estudo: Café com Freire. E-mail: paulogogia@hotmail.com

Adriana Maria Simião da Silva: Professora Associada da Universidade Regional do Cariri (URCA), Departamento de Ciências Sociais.

E-mail: adriana.simiao@urca.br ORCID: adriana.simiao@urca.br

\section{Tramitação:}

Recebido em:26/11/2021

Aprovado em: 10/12/2021 